\title{
A new species of non-lichenized ascomata from India
}

\section{Logesh $\mathrm{AR}^{1,2^{*}}$, Kalaiselvam $\mathrm{M}^{1}$ and Upreti $\mathrm{DK}^{2}$}

\author{
${ }^{1}$ Mycology Laboratory, Centre of Advanced Study in Marine Biology, Faculty of Marine Sciences, Annamalai \\ University, Porto Novo - 608502, Tamil Nadu, India. \\ ${ }^{2}$ Lichenology Laboratory, Plant Biodiversity, Systematics and Herbarium Division, CSIR - National Botanical \\ Research Institute, Lucknow - 226001. Uttar Pradesh, India. \\ marinefungi@gmail.com
}

Logesh AR, Kalaiselvam M, Upreti DK 2013 - A new species of non-lichenized ascomata from India. Mycosphere 4(1), 152-154, Doi 10.5943/mycosphere/4/1/10

Hysterographium palamalaiense is characterized by hysterothecium ascomata with sulcus at the centre, cylindrical 8-spored asci with muriform ascospores described here as new to science.

Key words - Hysterographium - Hysteriaceae - Palamalai hills

Article Information

Received 8 January 2013

Accepted 25 February 2013

Published online 28 February 2013

*Corresponding author: A. R. Logesh - e-mail - marinefungi@gmail.com

\section{Introduction}

The family Hysteriaceae is characterized by oval to ellipsoid ascomata with a long sulcus, bitunicate 8-spored asci, and apically free paraphyses or, in some cases, pseudoparaphyses (Checa et al. 2007). The family was monographed by Zogg (1962). The genus Hysterographium was monographed by Messuti \& Lorenzo (2003) in South America Tilak \& Kale (1964) contributed some information regarding the ascomycetes from India, but no comprehensive study has been carried out on this genus from India. During recent field trips to south Indian dry deciduous forests, one of the authors (ARL) collected a large number of interesting specimens, of which a new species of Hysterographium is described here.

\section{Methods}

Fresh specimens collected from the field were taken to the laboratory and air dried. The specimens were examined morphologi- cally by a Leica S8APO sterozoom microscope and anatomical observations were done by hand-cut sections mounted in water, $5 \% \mathrm{KOH}$ solution or $1 \%$ lugols solution and examined using a DM500 compound microscope. At least 50 asci and ascospores were measured. The type specimen is lodged in the herbarium of National Botanical Research Institute (LWG).

\section{The Species}

Hysterographium palamalaiense Logesh, Kalaiselvam \& Upreti sp. nov. Fig. 1 A-D. Mycobank No. MB 803099

Typus - India, Tamilnadu, Salem District, Palamalai Hills, $1 \mathrm{~km}$ towards Kemmampatty village, $700 \mathrm{~m}$, on Ficus sp., 24.7.2012, A.R. Logesh, 12-017735 (LWG holotypus).

Thallus corticolous, smooth on surface, greyish to white; algal layer absent, no photobiont. Ascomata sessile, modified to 

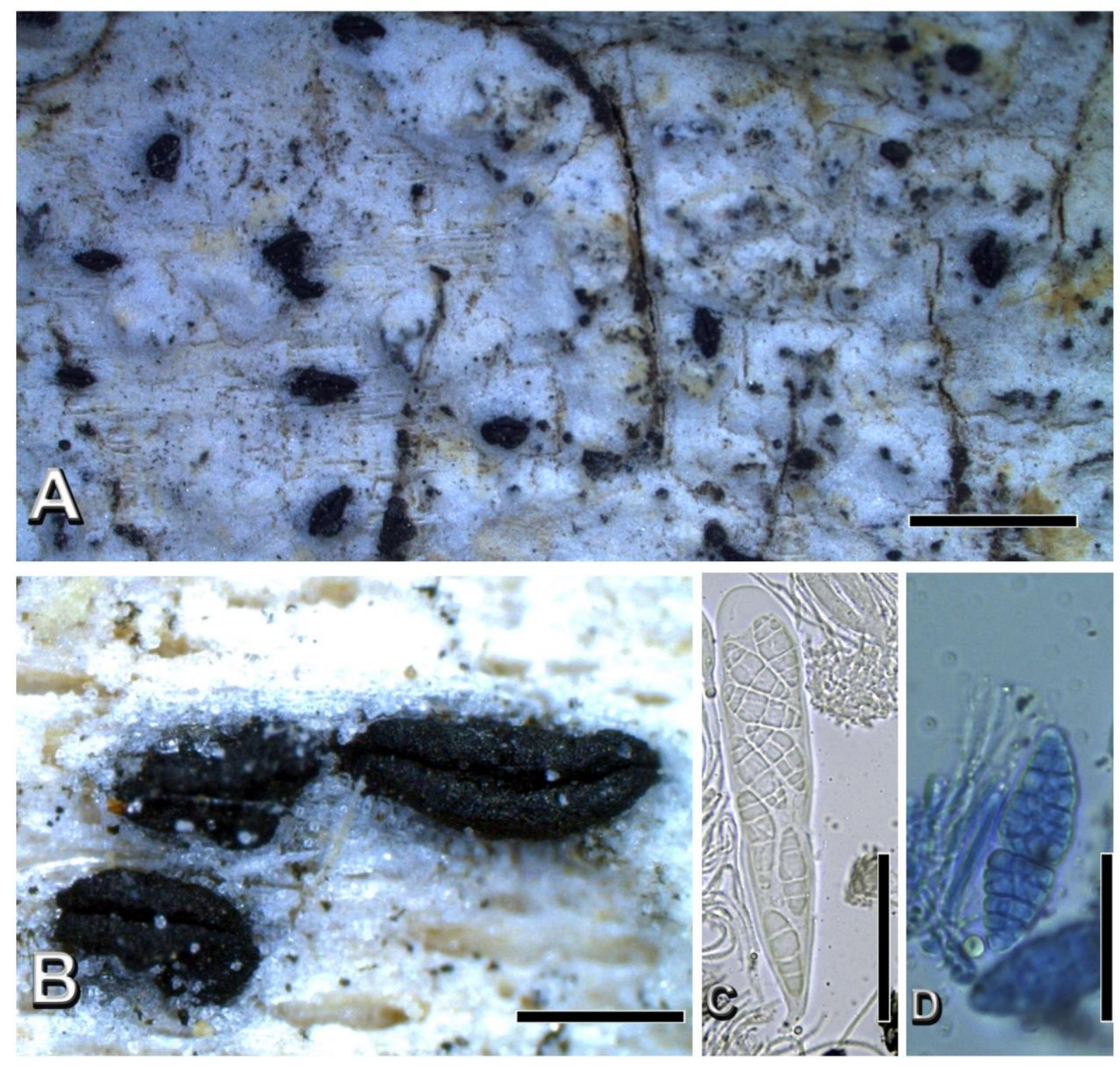

Fig.1 - Hysterographium palamalaiensis. A - Thallus with apothecia (holotype). B - Hysterioid apothecia. $\mathbf{C}$ - asci containing ascospores. D - Muriform ascospores. Scales A $=2 \mathrm{~mm} \mathrm{~B}=0.05 \mathrm{C}$ $=20 \mu \mathrm{m} \mathrm{D}=20 \mu \mathrm{m}$

hysterothecium, boat shaped, 1.0-2.0 mm consistently, dark brown to black, sulcus central. Labia entire, excipulum completely carbonized, ascocarp wall in section mostly 15-20 $\mu \mathrm{m}$ thick. Paraphyses numerous, 1-2 $\mu \mathrm{m}$ wide, without septa, with guttules. Asci bitunicate, clavate to cylindrical, numerous, long stacked, 8-spored, 115-160 × 20-30 $\mu \mathrm{m}$. Ascospores terete, oval to ellipsoid, muriform, consistently with 3-5 transverse septa and 1 vertical septa, straight to inequilateral septum, (20-)22-33(-35) × 8-13 $\mu \mathrm{m}$.

Etymology - The species name refers to the area where the specimen was collected.
Distribution - Hysterographium palamalaiense is known from only the type locality growing on Ficus trees at an altitude of $700 \mathrm{~m}$ in dry deciduous forest of south India (Palamalai Hills).

Notes - The new species is characterized by boat shaped hysterothecium and muriform ascospores. The septation of the spores is $3-5$ transverse and mostly 1 vertical septa. This species is differentiated from Opegrapha species with muriform ascopores by the absence of algal cells in the ascomata section. I/KI reactions on the hymenium give a negative reaction whereas in the case of Opegrapha sp. it gives a positive reaction (Ertz 
\& Diederich 2007). A comparison of this species with the other species of Hysterographium, revealed its unique characters with the hymenium, asci and ascospore sizes. The species is present in the particular area in large numbers; most of the ascomata were present on dead bark of Ficus sp. Lee \& Crous (2003) revised the hysteriaceous ascomycetes and studied their diversity in fynbos, followed by Lorenzo \& Messuti (2007) studied the genus Hysterium from the Farlow Herbarium.

\section{Acknowledgements}

The authors thank the Director, CSIRNational Botanical Research Institute, Lucknow for providing necessary facilities to carry out the work.

\section{References}

Checa J, Shoemaker RA, Umaña L. 2007. Some new hysteriaceous Fungi from Costa Rica. Mycologia 99, 285-290.
Ertz D, Diederich P. 2007. Revision of the Opegrapha species with muriform ascospores (previously Dictyographa) (lichenized Roccellaceae). The Lichenologist 39, 143-151.

Lee S, Crous PW. 2003. Taxonomy and biodiversity of hysteriaceous ascomycetes in fynbos. South African Journal of Botany 69, 480-488.

Lorenzo LE, Messuti MI. 2007. The specimens of Hysterium lineare (Hysteriaceae, Ascomycota) in the Farlow Cryptogamic Herbarium. Bol. Soc. Argent. Bot. 42(1-2), 25-28.

Messuti MI, Lorenzo LE. 2003. Notes on the genus Hysterographium (Ascomata, Hysteriaceae) in southern South America. Nova Hedwigia 76, 451-458.

Tilak ST, Kale SB. 1964. Contribution to our knowledge of Ascomycetes of India. Ferdinand Berger \& Sohne Ges.m.b.H., Horn. Austria.

Zogg H. 1962. Die Hysteriaceae s. str. und Lophiaceae. Beitrage Kryptogamenflora Schweiz 11(3), 1-190. 